\title{
Intellectual Capital Disclosure of Hungarian and Czech Listed Firms
}

\author{
Edit Lippai-Makra - Zsolt Rádóczi - Zsuzsanna Ilona Kovács*
}

\begin{abstract}
:
The purpose of this paper is to investigate the level of intellectual capital (IC) disclosure of the largest Czech and Hungarian listed firms. We apply content analysis of the annual statements and measure IC disclosure by a score. We hypothesize that a significant positive relationship exists between IC disclosure score and such firmspecific financial factors as company size, profitability, book value of intangibles and trade volume. The results of the regression model indicate that among the chosen independent variables, capitalized intangibles and profitability have a significant impact. Another contribution of the paper is the comparison of the two aforementioned Central European countries, which can serve as a basis for future research about the reporting culture of the region.
\end{abstract}

Key words: intellectual capital; voluntary disclosure; content analysis.

JEL classification: M410

\section{Introduction}

Present financial accounting regulations seem to provide a narrow space for intangibles on balance sheets. This is so because of the so-called recognition criteria - the rules that define which items are capitalized by the reporting entities. As within knowledge economy intangibles have been and probably will be the drivers of business, companies must find a way to communicate about them with their stakeholders. The problem is that these intellectually-based types of resources often have significant uncertainties related to their measurement and the economic benefits they provide. This means that entities are challenged when they try to apply the traditional accounting and controlling mechanisms when it comes to intangible

\footnotetext{
Edit Lippai-Makra; University of Szeged, Faculty of Economics and Business Administration, Institute of Finance and International Economic Relations, Kálvária sgt. 1., 6722 Szeged, Hungary, <makra.edit@eco.u-szeged.hu>.

Zsolt Rádóczi; University of Szeged, Faculty of Economics and Business Administration, Institute of Finance and International Economic Relations, Kálvária sgt. 1., 6722 Szeged, Hungary, <radoczi.zsolt@eco.u-szeged.hu>.

Zsuzsanna Ilona Kovács; University of Szeged, Faculty of Economics and Business Administration, Institute of Finance and International Economic Relations, Kálvária sgt. 1., 6722 Szeged, Hungary, <zsuzsanna.k@eco.u-szeged.hu>.

This research was supported by the project nr. EFOP-3.6.2-16-2017-00007, titled Aspects on the development of intelligent, sustainable and inclusive society: social, technological, innovation networks in employment and digital economy. The project has been supported by the European Union, co-financed by the European Social Fund and the budget of Hungary.
} 
Lippai-Makra, E. - Rádóczi, Z. - Kovács, I. Z.: Intellectual Capital Disclosure of Hungarian and Czech Listed Firms

assets (Deák and Lukovics, 2014). As a consequence, standards like the International Financial Reporting Standards (IFRS) - used globally by publicly listed companies - apply a conservative approach and define recognition criteria that lead to a very limited set of intangible assets presented in financial reports. The case of internally generated intangible resources is the most complicated when it comes to capitalization, since there is no related market transaction as an anchor for valuation. Consequently, only development costs and know-how are classified on the balance sheets, but only when some strict requirements are met. Novák (2018) focused on the disclosed information related to intangible assets in annual financial statements of a final sample of 22 entities listed on the Prague Stock Exchange in accordance with the requirements of IAS 38. The author found a poor level of disclosure of intangible assets, and the highest compliance score was achieved by manufacturing companies.

According to Petty, Cuganesan, Finch and Ford (2009), there is a consensus that intellectual capital can be broken down into human capital, internal capital and external capital. Sveiby refers to the intangible capital of the firms as something that can be presented in the 'invisible balance sheets' of the entities and defines the following three subcategories:

- individual competence including skills, education, experiences, values,

- internal structure including patents, concepts, models, computer and administrative systems and corporate culture

- external structure referring to relationships with customers and suppliers, brand names, trademarks and reputation or image (Sveiby, 2001, p. 64-66).

The magnitude of the off-balance sheet intangible items is often estimated by the market-to-book gap. The Brand Finance Global Intangible Finance Tracker (2018) has found that for the financial year $2017,52 \%$ of the overall enterprise value of all publicly traded companies worldwide resided in intangibles: $5 \%$ in disclosed intangible assets, $7 \%$ in disclosed goodwill and $40 \%$ in undisclosed value.

Reporting entities are required to provide their stakeholders with information that supports their financial decision making process. Financial accounting delivers the framework for this communication with external stakeholders by defining the content and the methodology. General purpose financial statements are published annually based on accounting standards which define the minimum compulsory content of the disclosed data. However, firms are also motivated to give additional voluntary disclosure attached to the mandatory sections to complete the picture with those items that do not fulfil the recognition criteria. Shehata (2014) discusses the role of voluntary disclosure in economy and lists several related theories: agency theory, signalling theory, capital need theory and legitimacy theory. The author mentions voluntary disclosure as a means of mitigating the 
agency problem, which derives from the information asymmetry existing between managers (as agents) and shareholders (as principals).

On one hand, voluntary disclosure can occur in the narrative parts of the accounts notes to numerical parts or Management's Report - where all firms are free to provide any additional details that they consider relevant. On the other hand, more and more entities publish some kind of non-financial statements like sustainability or corporate social responsibility reports to address those matters which are not typically included in general purpose financial statements. These documents may include significant information on intangible resources but are made on a voluntary basis and do not result in comparable data. In order to change that, a common conceptual basis should be established and disseminated on the markets. However, there is an emerging tendency for combining financial and non-financial statements in the form of integrated reports. According to KPMG (2017), 77\% of the largest European firms present corporate responsibility documents but Eastern Europe is lagging behind Western Europe.

Therefore, financial reports are the only source of information prepared and published by all entities. Consequently, the role of these reports is underlying as they can be considered the primary sources of information for those stakeholders who provide financing to firms (e.g. investors, lenders, creditors). In the following paragraphs, selected research studies will be presented which reveal the differences of intangible reporting cultures of firms from the chosen regions or countries.

Ragini's (2012) sample includes the largest Indian, US and Japanese firms (excluding banking, insurance and financial companies) and the author creates a disclosure index of 180 intangible items classified into the following groups: research and development, strategy and competition, market and consumer, human resource, intellectual property rights and goodwill, corporate and shareholder information, environment and others. According to the results, all countries show a significant improvement in their overall disclosure scores over the five year period (2001-2005). The study also highlights some independent variables associated with the disclosure scores: in the case of Indian entities it was organisational size and profitability, for the US companies it represented the industry type and in the case of Japanese companies, organisational size was mentioned (Ragini, 2012).

Kang and Gray (2011) examine the extent of intangible asset disclosure of emerging market companies for the year 2002. The results of the study show that corporatespecific factors, such as the adoption of global (international) reporting systems (IFRS or USGAAP - Generally Accepted Accounting Principles in the US), industry type or price-to-book ratio are the key factors significantly associated with intangible assets disclosure. Country-specific factors including risks associated with economic policies and the legal systems are also found to be of key importance 
Lippai-Makra, E. - Rádóczi, Z. - Kovács, I. Z.: Intellectual Capital Disclosure of Hungarian and Czech Listed Firms

(Kang and Gray, 2011). Kumar (2013) led similar research on a sample of all U.S.listed Asian companies for the year 2007. The results reveal that larger firms, firms with greater ownership dispersion, firms with lower leverage and firms from hightechnology industries provide more voluntary disclosure of intangibles information. As for European reporting environments, Oliveira, Rodrigues and Craig (2006) examined 56 entities listed on the Portuguese Stock Exchange for the year 2003. The items were grouped into the three most commonly used intellectual capital categories: human capital, structural capital and relational capital. Results show that the disclosure of human capital-related information lags behind that of the other two categories.

Li, Pike and Haniffa (2008) examine the association between intellectual capital disclosure - applying the same three categories: human capital, structural capital and relational capital - and corporate governance structure. The sample of 100 companies listed on the London Stock Exchange was chosen from seven industry sectors (Pharmaceuticals and Biotechnology, IT, Telecommunications, Business Services, Media and Publishing, Banking and Insurance, Food Production and Beverage). The annual statements covered the financial years with the year-ends between March 2004 and February 2005. The authors apply a sophisticated methodology including measurement of a disclosure index score supported by word count and percentage of word count metrics which makes it possible to assess not only the volume but the variety and the focus of the intellectual capital statements. The independent variables included board composition, ownership structure, audit committee size, frequency of audit committee meetings and CEO role duality. Research results indicate a significant association with all the governance factors except for the latter. The list of the 61 intellectual capital items (22 for human capital, 18 for structural capital and 21 for relational capital, see Table 1) was presented in Li, Pike and Haniffa's (2008) paper and later adopted by other researchers.

Boujelbene and Affes (2013) apply Li, Pike and Haniffa's (2008) index in order to compose an independent variable in their study. The aim of their research is to examine the impact of intellectual capital disclosure on the cost of equity capital as the dependent variable. Data is based on companies listed in the French SBF 120 stock market index, with a final sample of 102 annual reports. The authors distinguish between high-tech industries and traditional industries and state that there is extensive disclosure of intellectual capital information by the French firms. The study also concludes that there is a significant and negative association between intellectual capital disclosure with its two components (human capital, structural) and the cost of equity (Boujelbene and Affes, 2013). 
Tab. 1: Intellectual capital items listed by Li, Pike and Haniffa (2008)

\begin{tabular}{|c|c|c|}
\hline Human Capital & Structural Capital & Relational Capital \\
\hline 1. Number of employees & Intellectual property & 1. Customers \\
\hline 2. Employee age & Process & 2. Market presence \\
\hline 3. Employee diversity & Management philosophy & 3. Customer relationships \\
\hline 4. Employee equality & Corporate culture & 4. Customer acquisition \\
\hline 5. Employee relationship & Organisation flexibility & 5. Customer retention \\
\hline 6. Employee education & Organisation structure & 6. CTE \\
\hline 7. Skills/know-how & Organisation learning & 7. Customer involvement \\
\hline $\begin{array}{l}\text { 8. Employee work-related } \\
\text { competences }\end{array}$ & $\begin{array}{l}\text { 8. Research \& development } \\
(\mathrm{R} \& \mathrm{D})\end{array}$ & 8. Company image/reputation \\
\hline 9. Employee work-related knowledge & Innovation & 9. Company awards \\
\hline 10. Employee attitudes / behaviour & 10. Technology & 10. Public relation \\
\hline 11. Employee commitments & 11. Financial dealings & 11. Diffusion \& networking \\
\hline 12. Employee motivation & $\begin{array}{l}\text { 12. Customer support } \\
\text { function }\end{array}$ & 12. Brands \\
\hline 13. Employee productivity & $\begin{array}{l}\text { 13. Knowledge-based } \\
\text { infrastructure }\end{array}$ & 13. Distribution channels \\
\hline 14. Employee training & $\begin{array}{l}\text { 14. Quality management and } \\
\text { improvement }\end{array}$ & 14. Relationship with suppliers \\
\hline 15. Vocational qualifications & 15. $\begin{array}{l}\text { Accreditations } \\
\text { (certificate) }\end{array}$ & 15. Business collaboration \\
\hline 16. Employee development & $\begin{array}{l}\text { 16. Overall infrastructure / } \\
\text { capability }\end{array}$ & 16. Business agreements \\
\hline 17. Employee flexibility & 17. Networking & 17. Favourite contract \\
\hline 18. Entrepreneurial spirit & 18. Distribution network & 18. Research collaboration \\
\hline 19. Employee capabilities & & 19. Marketing \\
\hline 20. Employee teamwork & & $\begin{array}{l}\text { 20. Relationship with } \\
\text { stakeholders }\end{array}$ \\
\hline $\begin{array}{l}\text { 21. Employee involvement with } \\
\text { community }\end{array}$ & & 21. Market leadership \\
\hline 22. Other employee features & & \\
\hline
\end{tabular}

Source: Li, Pike and Haniffa (2008)

Ho, Chau and Cheing (2012) analysed the impact of intellectual capital disclosure on the initial public offering (IPO) of shares listed on the Hong Kong Stock Exchange. The sample included a randomly selected 60 Hong Kong IPOs listed from 2008 to 2010. The empirical results suggest that intellectual capital disclosure has a significant and positive influence on the level of investor confidence in the IPO. Empirical evidence supports the notion that firms benefit from the voluntary exposure of intellectual capital items to investors, as it reduces their uncertainties related to the investment. 
Lippai-Makra, E. - Rádóczi, Z. - Kovács, I. Z.: Intellectual Capital Disclosure of Hungarian and Czech Listed Firms

Bogdan, Platon and Popa (2011) also carry out a content analysis of annual reports of the companies listed on the Bucharest Stock Exchange (BSE) over five year period (2005-2009) based on the model elaborated by Li, Pike and Haniffa (2007). The paper also examines the evolution of the market-to-book value ratio for the sampled 19 manufacturing companies, which were selected on the basis of their knowledge-based assets and incentives to disclose intellectual capital. The authors' conclusion is that although the average scores had increased for the selected companies during the period, Romanian manufacturing companies still show low interest for reporting intellectual capital (Bogdan, Platon and Popa, 2011). Petty, Cuganesan, Finch and Ford (2009) state that the greatest obstacles for firms wishing to adopt intellectual capital reporting are the lack of consistency in methodologies for disclosure and the difficulties in assigning meaningful and reliable quantitative values to knowledge-based items.

Our empirical research carried out earlier (Kovács 2015) was based on Ragini’s (2012) methodology and concluded that the intangible reporting practice of the largest Hungarian sample entities was basically determined by the requirements of the regulations. Listed companies - which are required to enclose Management Commentary to the financial statements - were exceptions: in their case voluntarily released information was also significant. The purpose of this paper is to investigate the level of intellectual capital disclosure of the largest Czech and Hungarian listed firms. We hypothesize that significant relationship exists between IC disclosure and such firm-specific financial factors as company size, profitability, the book value of intangibles and trade volume.

\section{Data and Methodology}

Our research presented in this paper is a pilot project aiming to provide basis for future analysis. We apply the methodology elaborated by Li, Pike and Haniffa (2008) to examine the intellectual capital disclosure practices of Hungarian listed firms. Czech listed firms were also included to provide opportunity for comparison between the reporting cultures of the two countries. On one hand, these two countries have been both characterised by the post-communist transition and they also have similarities in their growth paths (Farkas 2011). On the other hand, according to Albu, Albu and Filip (2017), the financial reporting infrastructure needed significant improvement in these countries (similarly to other Central and Easter European economies). However, other Central European countries were not included at this phase because of the differences regarding population and number 
of publicly listed enterprises ${ }^{1}$ (Csiki and Kiss, 2018; Kiss and Vychytilová, 2017). One of our research aims is to spot any similarities or differences between the sample firms from the two countries providing basis for future research. Our first hypothesis is as follows:

H1: the level of IC disclosure for the Czech and Hungarian sample firms is expected to be similar.

We also made an attempt to find some company-specific independent variables which have significant impact on the disclosure scores. Based on the literature cited above we assume that larger, more profitable, intangible-intensive and more frequently traded companies tend to publish more details on their intellectual capital in their annual statements. Therefore, we hypothesize that:

$\mathrm{H} 2$ : There is a positive relationship between the level of IC disclosure and the given firm's size, profitability, book value of intangibles and the trading volume.

At this level of empirical research, our pilot test was carried out on a small sample for the accounting year 2017 so that the most recent available source of annual reports is processed for both countries. From the Hungarian Stock Exchange, we chose the 10 largest publicly listed entities based on their sales revenue in the financial year $2017^{2}$. We excluded the banking and insurance sector at this phase due to the fact that financial institutions have different reporting requirements and special features compared to the other sectors. The annual statements were downloaded from the webpage of the Budapest Stock Exchange ${ }^{3}$. In case of the Czech listed firms, we downloaded the reports from the webpage of the Prague Stock Exchange.

We chose premium category firms, as they present their annual statements in English and we have arrived at the final sample of 7 firms, also excluding financial institutions and insurance companies ${ }^{4}$. Since we found several crossreferences in the annual statements to different additional reports published by the firms, we have also included those in the analysis. In order to do that, the webpages of the entities were also visited and sustainability or CSR reports published for 2017 were downloaded and checked. We aimed to process the entire information package

\footnotetext{
${ }^{1}$ The number of publicly listed entities is 40 on the Budapest Stock Exchange (bet.hu/oldalak/kibocsatok) and 54 on the Prague Stock Exchange (pse.cz/en/marketdata/statistics/market-capitalisation-summary/).

${ }^{2}$ We considered Elmü and Émász as one entity.

${ }^{3} \mathrm{https}: / / \mathrm{www} \cdot$ bet.hu/oldalak/kibocsatok

${ }^{4}$ https://www.pse.cz/en/market-data/shares/prime-market/
} 
Lippai-Makra, E. - Rádóczi, Z. - Kovács, I. Z.: Intellectual Capital Disclosure of Hungarian and Czech Listed Firms

that is available for the interested parties related to 2017. The sample includes firms from several sectors, including manufacturing and service-based companies as well.

When analysing the content of the reports - similarly to Bellora and Guenther (2013) - we chose to read and score the statements manually because we intended to rely on our understanding of the published data instead of computer software. We chose the methodology elaborated by Li, Pike and Haniffa (2008) because it provides a comprehensive list of items together with explanations of the items which helps understanding and supports consistency of the research. The authors constructed a research instrument covering 61 intellectual capital (IC) items relating to the three mentioned categories: human capital (HIC: 22 items), structural capital (SIC: 18 items), and relational capital (RIC: 21 items) and searched the reports for the respective items in the form of a text, numerical information and graphical/pictorial demonstration. The approach applied in the study was dichotomous: an item scored one if it was disclosed and zero if it was not (the use of weighted coding was not opted for). Consequently, the maximum score available is $183(61 * 3)$. Similarly to Kuralová and Margarisová (2016), we considered the negative statements to items (it is stated that the item is not included in the report) as a higher level of disclosure than the omission of the given piece of information, so we gave a score of one in case the item was lacking from the document but it was mentioned or when it was mentioned as a desirable but currently missing phenomena at the entity.

\section{Results and Discussion}

In both the Hungarian and Czech sample, the most frequently reported human capital items in all the three forms (text, numerical, graphic) is the number of employees. In case of Hungarian firms, in the text and numerical form, employee relationship is also commonly disclosed and the same is true for employee motivation for the Czech entities. Employee training/employee education is also often reported as a text, and other employee features were displayed on a graph or a picture in the case of at least half of the sample firms.

All Czech firms reported intellectual property, process, management philosophy, organisation flexibility, organisational structure, innovation, technology and financial dealings from the structural capital section. At least 9 from the 10 Hungarian companies added process, management philosophy, organisational structure and technology. Organisational structure was the most frequently disclosed graph in both countries.

In the relational capital category, customer and market presence items scored the highest. For Hungarian firms, these were followed by the relationship with suppliers and business collaboration. For Czech companies, customer relationships, business 
agreement and relationship with stakeholders were also popular. Graphic demonstration was most common in the case of the Hungarian sample for market presence, while more than half of the Czech firms also added brands and relationship with stakeholders in this format.

Customer support function, customer involvement, and favourite contract were very rarely disclosed by Hungarian entities. Almost all Czech firms omitted employee productivity and employee teamwork, among others.

The core dependent variable measured for Li, Pike and Haniffa (2008, p. 149) was ICDI $(36 \%)$, the variety of IC disclosure, measured as the number of items in the research instrument disclosed in the annual report divided by 183 . HICDI (35.5\%), SICDI (37.1\%) and RICDI (36.5\%) were also calculated for the three subcategories. If we examine the disclosure intensity of the Czech sample (see Table 2), we find that, on average, $37.5 \%$ of the IC items included in the index were reported (ICDI). In terms of the subcategories, HICDI is $34 \%$, SICDI is $42.6 \%$ and RICDI is $36.7 \%$. As for Hungary, ICDI is lower than that of the Czech sample: $31.8 \%$.

Yet, we applied an individual T-test for the disclosure scores of the sample entities from the two countries and concluded that there is no significant difference between the average scores, which means that data does support our first hypothesis (H1).

The ranking between the variables for the relative disclosure within subcategories is the same: HICDI: $26.7 \%$, SICDI: $39.3 \%$ and RICDI: $30.8 \%$. This means that for both countries, structural capital had the highest relative disclosure score, followed by relational capital and human capital.

Standard deviation of the disclosure scores of entities are high for both sample countries but even higher for Hungary, which means that firms' reporting practices are quite diverse. Regarding the forms of disclosure, in all subcategories the extent of reporting is the most intense in the text form, followed by the numerical depiction and the graphical demonstration ranking as the last. On average, 8 graphic or pictorial disclosures were found in the Hungarian reports and 10 in the Czech statements. The recommendation issued by the European Commission (2017) about non-financial reporting is also supporting visual representation as it makes communication more effective and transparent.

The following theoretical model was considered for regression:

$$
\begin{gathered}
\ln \left(\text { Score }_{c o}\right)=\omega+\beta_{1} \ln \left(\text { Revenue }_{c o}\right)+\beta_{2} \ln \left(\text { Pretaxprofit }_{c o}\right)+ \\
\beta_{3} \ln \left(\text { BSSize }_{c o}\right)+\beta_{4} \ln \left(\text { Immat }_{\text {co }}\right)+\beta_{5} \ln \left(\text { Volume }_{c o}\right)+ \\
\beta_{6}\left(\text { dummy }_{\text {country }}\right)+\varepsilon
\end{gathered}
$$


Lippai-Makra, E. - Rádóczi, Z. - Kovács, I. Z.: Intellectual Capital Disclosure of Hungarian and Czech Listed Firms

Tab. 2: Descriptive statistics for IC disclosure in the Czech and Hungarian sample

\begin{tabular}{|c|c|c|c|c|c|c|c|}
\hline \multicolumn{8}{|l|}{ Czech sample } \\
\hline $\begin{array}{l}\text { Intellectual Capital } \\
\text { Categories }\end{array}$ & Format & Min & Max & $\begin{array}{r}\text { Max } \\
\text { possible }\end{array}$ & Mean & $\%$ & SD \\
\hline \multirow[t]{4}{*}{ Human } & Numerical & 1 & 12 & 22 & 6.3 & 28.6 & 3.8 \\
\hline & Text & 2 & 19 & 22 & 12.1 & 55.2 & 6.0 \\
\hline & Graph & 0 & 11 & 22 & 4.0 & 18.2 & 4.0 \\
\hline & All & 4 & 42 & 66 & 22.4 & 34.0 & 13.0 \\
\hline \multirow[t]{4}{*}{ Structural } & Numerical & 3 & 10 & 18 & 6.6 & 36.5 & 2.1 \\
\hline & Text & 9 & 17 & 18 & 13.1 & 73.0 & 2.9 \\
\hline & Graph & 1 & 8 & 18 & 3.3 & 18.3 & 2.4 \\
\hline & All & 13 & 32 & 54 & 23.0 & 42.6 & 6.3 \\
\hline \multirow[t]{4}{*}{ Relational } & Numerical & 1 & 10 & 21 & 6.9 & 32.7 & 2.9 \\
\hline & Text & 4 & 19 & 21 & 12.9 & 61.2 & 4.8 \\
\hline & Graph & 1 & 8 & 21 & 3.4 & 16.3 & 2.3 \\
\hline & All & 6 & 32 & 63 & 23.1 & 36.7 & 8.8 \\
\hline \multirow[t]{4}{*}{ All } & Numerical & 9 & 27 & 61 & 19.7 & 32.3 & 6.8 \\
\hline & Text & 19 & 54 & 61 & 38.1 & 62.5 & 13.1 \\
\hline & Graph & 2 & 19 & 61 & 10.7 & 17.6 & 6.8 \\
\hline & All & 30 & 100 & 183 & 68.6 & 37.5 & 25.8 \\
\hline \multicolumn{8}{|l|}{ Hungarian sample } \\
\hline $\begin{array}{l}\text { Intellectual Capital } \\
\text { Categories }\end{array}$ & Format & Min & Max & $\begin{array}{r}\text { Max } \\
\text { possible }\end{array}$ & Mean & $\%$ & SD \\
\hline \multirow[t]{4}{*}{ Human } & Numerical & 1 & 11 & 22 & 4.9 & 22.3 & 3.7 \\
\hline & Text & 1 & 18 & 22 & 9.8 & 44.5 & 7.5 \\
\hline & Graph & 0 & 9 & 22 & 2.9 & 13.2 & 3.1 \\
\hline & All & 2 & 36 & 66 & 17.6 & 26.7 & 13.5 \\
\hline \multirow[t]{4}{*}{ Structural } & Numerical & 2 & 13 & 18 & 6.1 & 33.9 & 3.0 \\
\hline & Text & 5 & 17 & 18 & 11.7 & 65.0 & 4.1 \\
\hline & Graph & 0 & 12 & 18 & 3.4 & 18.9 & 3.7 \\
\hline & All & 8 & 37 & 54 & 21.2 & 39.3 & 9.8 \\
\hline \multirow[t]{4}{*}{ Relational } & Numerical & 1 & 12 & 21 & 6.1 & 29.0 & 4.0 \\
\hline & Text & 4 & 19 & 21 & 11.2 & 53.3 & 5.7 \\
\hline & Graph & 0 & 5 & 21 & 2.1 & 10.0 & 2.0 \\
\hline & All & 5 & 36 & 63 & 19.4 & 30.8 & 11.5 \\
\hline \multirow[t]{4}{*}{ All } & Numerical & 5 & 36 & 61 & 17.1 & 28.0 & 9.9 \\
\hline & Text & 13 & 52 & 61 & 32.7 & 53.6 & 16.4 \\
\hline & Graph & 0 & 22 & 61 & 8.4 & 13.8 & 8.2 \\
\hline & All & 20 & 109 & 183 & 58.2 & 31.8 & 33.2 \\
\hline
\end{tabular}

Source: authorial computation

where corporate size was represented by the logarithm of the total assets and revenue; profitability by the logarithm of profit before tax, the importance of intangible assets with the logarithm of their book value, while their popularity on the stock market is represented by the logarithm of their trade volume. The Czech and Hungarian affiliation was represented with a country-sensitive dummy (0: 
Hungarian, 1: Czech). We expect that all financial and market-related data can increase the score, while the significance of the dummy variable highlights the heterogeneity of the sample. Natural logarithms were used to scale the data. The model was tested trough OLS regression following Kiss (2017).

\section{Tab. 3: OLS regression results}

\begin{tabular}{|c|c|c|c|c|}
\hline $\begin{array}{l}\text { Dependent variable: } \\
\ln (\text { score })\end{array}$ & Coefficient & std. error & t-ratio & p-value \\
\hline const & 2.80165 & 1.10003 & 2.547 & $0.0290 * *$ \\
\hline dummy & 0.0154122 & 0.286484 & 0.05380 & 0.9582 \\
\hline $\ln ($ revenue) & -0.114760 & 0.180841 & -0.6346 & 0.5399 \\
\hline $\ln ($ PTprofit) & 0.0339155 & 0.0179574 & 1.889 & $0.0883 *$ \\
\hline $\ln ($ PTprofit) & 0.0339155 & 0.0179574 & 1.889 & $0.0883 *$ \\
\hline $\ln (\mathrm{TA})$ & 0.0234510 & 0.145635 & 0.1610 & 0.8753 \\
\hline $\ln (\operatorname{Int})$ & 0.165387 & 0.0674828 & 2.451 & $0.0342 * *$ \\
\hline In(volume) & -0.0120538 & 0.0310627 & -0.3880 & 0.7061 \\
\hline Mean dependent var & & 3.998978 & S.D. dependent var & 0.570518 \\
\hline Sum squared resid & & 1.677378 & S.E. of regression & 0.409558 \\
\hline R-squared & & 0.677914 & Adjusted R-squared & 0.484662 \\
\hline$F(6,10)$ & & 3.507933 & P-value(F) & 0.039110 \\
\hline Log-likelihood & & -4.436110 & Akaike criterion & 22.87222 \\
\hline Schwarz criterion & & 28.70471 & Hannan-Quinn & 23.45198 \\
\hline
\end{tabular}

Test for null hypothesis of normal distribution: Chi-square $(2)=5.316$ with p-value 0.07009

Source: authorial computation

The results were back tested with similar results on a reduced model as well, however, the normality of the residuals were maintained only by this original model. The outcome of the regression evaluates the second hypotheses ( $\mathrm{H} 2)$ that there is a baseline value for the score (represented by the constant), but the importance of the intangible variables had the biggest impact on scores. Meanwhile profit had lower influence as well as revenues, corporate size, trade volume or country had no influence at all.

Direct comparison of our findings with Li, Pike and Haniffa's (2008), results is not possible, not only because of the different time span of the reports but because such content analysis is very sensitive to subjective interpretation of the items, and there is a need for a common understanding of the methodology among the coders. However, we can conclude that there is a basis for future research regarding the extent of intellectual capital disclosure comparing Western and Central-Eastern European samples. The possible disclosure lag experienced in the case of the Hungarian entities is an important subject which shall be investigated in the future. 
Lippai-Makra, E. - Rádóczi, Z. - Kovács, I. Z.: Intellectual Capital Disclosure of Hungarian and Czech Listed Firms

\section{Conclusion}

Results indicate that the IC reporting culture of Czech and Hungarian sample firms is similar: they prefer the text form of reporting and disclose relatively the most items in the structural capital subcategory, followed by relational capital and human capital. Regression results pointed out the book value of intangibles and profit before tax as firm-specific financial characters that have significant positive influence on disclosure scores.

There are several limitations to this study. First of all, this was our first attempt to apply content analysis on an international sample and the size of the sample was small at this stage of research. In the future, there is basis for research with a sample embracing additional countries in order to grasp similarities or differences between not only Western and Easter European countries but within the CEE region as well. Finally, we focused on presented annual reports of the entities, while there are other sources of media which firms may use to communicate about their possessed intellectual capital items.

\section{References}

Albu, N., Albu, C.N., Filip, A., 2017. Corporate Reporting in Central and Eastern Europe: Issues, Challenges and Research Opportunities. Accounting in Europe 14, 249-260. DOI: 10.1080/17449480.2017.1385819.

Bellora, L., Guenther, T. W., 2013. Drivers of innovation capital disclosure in intellectual capital statements: Evidence from Europe. The British Accounting Review 45, 255-270. DOI: 10.1016/j.bar.2013.06.002.

Boujelbene, M. A., Affes, H., 2013. The impact of intellectual capital disclosure on cost of equity capital: A case of French firms. Journal of Economics Finance and Administrative Science 18, 45-53. DOI: 10.1016/S2077-1886(13)70022-2.

Bogdan, V., Platon, J., Popa, D. N., 2011. Intellectual capital reporting and disclosure in the annual reports of Romanian manufacturing listed companies methodology and discussion of results. Annals of Faculty of Economics 1, 466-476. Brand Finance, 2018. Global Intangible Finance Tracker (GIFT ${ }^{\mathrm{TM}}$ ) 2018 - an annual review of the world's intangible value. Available from: $<$ brandfinance.com/knowledge-centre/whitepapers/global-intangible-finance-track er-gift-2018/>.

Csiki, M., Kiss, G. D., 2018. Capital Market Contagion in the Stock Markets of Visegrád Countries Based on the Heckman Selection Model. Financial and Economic Review 17 (4): 23-52. 
Deák, I., Lukovics, M., 2014. Responsible Innovation and R\&D\&I Controlling in: Buzás, N., Lukovics, M. (eds.), Responsible Innovation, University of Szeged, Faculty of Economics and Business Administration, 101-119.

European Commission, 2017. Guidelines on non-financial reporting (methodology for reporting non-financial information) Communication from the Commission, 2017/C, 215/01.

Farkas, B., 2011. The Central and Eastern European model of capitalism. PostCommunist Economies 23 15-34. https://doi.org/10.1080/14631377.2011.546972

Ho, H., Chau, K., Cheung, P., 2012. Intellectual Capital Disclosure and Initial Public Offerings: Evidence from Hong Kong. Journal of Applied Economics and Business Research 2 (2): 56-68.

Kang, H. H., Gray, S. J., 2011. Reporting intangible assets: Voluntary disclosure practices of top emerging market companies. The International Journal of Accounting 46, 402-423. DOI: 10.1016/j.intacc.2011.09.007.

Kiss, G. D., Vychytilová, J., 2017. Macroeconomic Background of Public Listing in Czechia and Hungary. In: Proceedings of the 8th International Scientific Conference. Tomas Bata University, Zlín.

Kiss, G. D., 2017. Volatilitás, extrém elmozdulások és tőkepiaci fertőzések. Szeged, JATEPress Kiadó.

Kovács, Zs. I., 2015. Immaterial Assets in the Hungarian Accounting System and Financial Statements. Public Finance Quarterly 60 (2):231-242

KPMG International 2017. The KPMG Survey of Corporate Responsibility Reporting 2017.

Kumar, G., 2013. Voluntary disclosures of intangibles information by U.S.-listed Asian companies. Journal of International Accounting, Auditing and Taxation 22, 109-118. DOI: 10.1016/j.intaccaudtax.2013.07.002.

Kuralová, K., Margarisová, K., 2016. Intellectual Capital Disclosure at Czech Public Universities in Relation to the Stakeholder Information Need. Acta Universitatis Agriculturae et Silviculturae Mendelianae Brunensis 64, 1989-1998. DOI: $10.11118 /$ actaun201664061989.

Li J., Pike R., Haniffa R., 2007. Intellectual Capital Disclosure in Knowledge rich Firms: The impact of Market and Corporate Governance Factors. Working paper 07/06, april 2007, Available from: <brad.ac.uk/acad/management/external/pdf/w orkingpapers/2007/Booklet_07-06.pdf>.

Li, J., Pike, R., Haniffa, R., 2008. Intellectual capital disclosure and corporate governance structure in UK firms. Accounting and Business Research 38, 137-159. DOI: $10.1080 / 00014788.2008 .9663326$. 
Lippai-Makra, E. - Rádóczi, Z. - Kovács, I. Z.: Intellectual Capital Disclosure of Hungarian and Czech Listed Firms

Novák, M., 2018. The Quality of Disclosure under IAS 38 in Financial Statements of Entities Listed on PSE. European Financial and Accounting Journal 2018, 3144. DOI: $10.18267 /$ j.efaj.208.

Oliveira, L., Lima, R. L., Craig, R., 2006. Firm-specific determinants of intangibles reporting: evidence from the Portuguese stock market. Journal of Human Resource Costing \& Accounting 10, 11-33. DOI: 10.1108/14013380610672657.

Petty R. M., Cuganesan S., Finch N., Ford G. 2009. "Intellectual Capital and Valuation: Challenges in the Voluntary Disclosure of Value Drivers." Journal of Finance and Accountancy, Academic and Business Research Institute 1, 1-7. Available from: 〈http://www.aabri.com/manuscripts/09177.pdf>.

Ragini, 2012. Corporate Disclosure of Intangibles: A Comparative Study of Practices among Indian, US, and Japanese Companies. Vikalpa 37, 51-72. DOI: $10.1177 / 0256090920120305$.

Shehata, N.F., 2014. Theories and Determinants of Voluntary Disclosure. Accounting and Finance Research 3. DOI: doi.org/10.5430/afr.v3n1p18.

Sveiby, K. E., 2001. Szervezetek új gazdagsága: a menedzselt tudás. KJK KERSZÖV, Budapest. 
European Financial and Accounting Journal, 2019, vol.14, no. 3, pp. 45-60

\section{Appendix 1: Financial data of the sample entities (thousand HUF)}

\begin{tabular}{|c|c|c|c|c|c|c|}
\hline Entity & Country & $\begin{array}{c}\text { Sales } \\
\text { Revenue }\end{array}$ & $\begin{array}{c}\text { Profit Before } \\
\text { Tax } \\
\end{array}$ & Total Assets & $\begin{array}{c}\text { Intangible } \\
\text { assets }\end{array}$ & $\begin{array}{l}\text { Trading } \\
\text { Volume } \\
\end{array}$ \\
\hline Mol & $\mathrm{HU}$ & 4130320000 & 365638000 & 4231700000 & 181451000 & 1475463 \\
\hline $\begin{array}{l}\text { Magyar } \\
\text { Telekom }\end{array}$ & $\mathrm{HU}$ & 610851000 & 56204000 & 1109661000 & 441458000 & 174890080 \\
\hline $\begin{array}{l}\text { Richter } \\
\text { Gedeon }\end{array}$ & $\mathrm{HU}$ & 444356000 & 13901000 & 760865000 & 199335000 & 97341018 \\
\hline $\begin{array}{l}\text { ELMÜ- } \\
\text { ÉMÁSZ }\end{array}$ & $\mathrm{HU}$ & 236736000 & 24720000 & 245405000 & 2430000 & 8902 \\
\hline Waberer's & $\mathrm{HU}$ & 209152833 & 7187495 & 211316060 & 2789342 & 1045497 \\
\hline Rába & $\mathrm{HU}$ & 43842346 & 2047913 & 36437867 & 282418 & 1090399 \\
\hline ANY & $\mathrm{HU}$ & 26180920 & 1904125 & 17672853 & 372435 & 3063965 \\
\hline Alteo & $\mathrm{HU}$ & 18389284 & 896491 & 16594999 & 759242 & 555652 \\
\hline $4 \mathrm{iG}$ & $\mathrm{HU}$ & 16914666 & -364869 & 8401204 & 1655334 & 2001210 \\
\hline KONZUM & $\mathrm{HU}$ & 16823847 & 11340160 & 66400176 & 59574 & 407896290 \\
\hline CETV & $\mathrm{CZ}$ & 148692 & 19560 & 421585 & 270024 & 64757352 \\
\hline Kofola & $\mathrm{CZ}$ & 84682513 & 3245656 & 80007587 & 14307672 & 159650250 \\
\hline CEZ & $\mathrm{CZ}$ & 2455439438 & 276706059 & 7615491189 & 325971485 & 1939558 \\
\hline $\mathrm{O} 2$ & $\mathrm{CZ}$ & 458590462 & 86320907 & 423724015 & 204492260 & 9099131213 \\
\hline PFN & $\mathrm{CZ}$ & 68626153 & 3868950 & 141459983 & 30171902 & 2698996310 \\
\hline TMR & $\mathrm{CZ}$ & 29734353 & 2430446 & 136103741 & 4384809 & 24501 \\
\hline VGP & $\mathrm{CZ}$ & 8770862 & 36420955 & 320875138 & 11187 & 1690691 \\
\hline
\end{tabular}

Source: authorial computation based on published (2017) annual statements of the sample entities and https://stooq.com/ 
